\title{
Preparation of new jams recipes using some un traditional agricultural resources
}

\author{
A. Sallam *; A. El-Beltagy ; A. El-Bedewy \\ Department of Food Science and Technology, Faculty of Agriculture, Menofia University, Egypt. \\ *Hero MEA, Vitrac factory, Tersa, Toukh, Qaloubia Governorate, Egypt. \\ Corresponding author: Abdullah.salam@ hero.com.eg
}

\begin{abstract}
In this study, the manufacture of new types of untraditional agricultural sources in the Egyptian market or the global market of fruit and vegetables and plant materials with high nutritional value and variety but is not used on a commercial scale. In the beginning was the use of mint, papaya and hibiscus of new types of jams and after sensory evaluation got samples jam papaya and and mint to accept sensory high. For this study tended to add vanilla pulp mango pulp apples to the work of the various combinations and after many sensory experiences by sensory arbitrators got seven combinations of high results of the evaluation of sensory high, namely, (jam hibiscus, mint jam and jam with papay mango pulp ratio of $25 \%$ ). The analysis of the raw materials used in the study is chemically and nutritionally the results showed the increase of these raw materials, vitamins and minerals and contain a percentage of protein and high content of carbohydrates. Three were analyzing samples prepared from non-traditional jam nutritionally and then these mixtures microbiology to study the safety evaluated by sensory evaluation and found to be safe from the microbiological. It was an experiment the jam with a concentration of $62^{\circ}$ Brix manufactured u was used in the rest of the study, therefore, was three mixtures manufactured in this way were chemically and nutritionally analyzed and Microbiology. It was measure the rheological properties the results of the analysis rheological that all selected mixtures behave non-Newton behaviour "pseudo plastic" with stress subordination has been studying the effect of temperature on the strength of these mixtures and found that heat a large effect on the strength of these foods has been the activation energy account and through these tests found These mixtures are of a good and proper strength.
\end{abstract}

Key words: Jam - nutritional value- sensory evaluation - physiochemical characteristics - microbiologically examination - rheological characteristics.

\section{Introduction}

In the recent period have increased demand for food and the desire for diversity of sources and alternatives due to the increase in the world population prompting scientists and researchers to search for ancient sources that were not used or did not improve their use as sources of food and modern and cheap sources and technologies.

Generally, Jam should contain at least $60 \%$ total soluble solids (T.S.S) and at least $45 \%$ fruit (The Prevention of Food Adulteration Rules, 1955, Santanu 2010), whereas, The Codex Alimentarius Commission specifies that the finished jam should contain more than $65 \%$ TSS. Sugar constitutes more than $40 \%$ of total weight and $80 \%$ of total solids in jam (Santanu, 2010).In 2013 a new Egyptian standard had been released which declared that the Jam (T.S.S) should be not less than $60 \%$ (EOS, 2013) .

Roselle orHibiscus sabdariffa L.is a genus of the Malvaceae family. A plant that is widely grown in tropical and subtropical regions especially Egypt, Sudan , Thailand, Mexico and China (Leung , 1996). The Roselle extract has a unique red color, good flavor, low sugar and high acid content, the acidity makes the juice sour hence the need for addition of sweetening products (MagayKilima ,2014).

Mentha has a high menthol content. Dried peppermint typically has $0.3-0.4 \%$ of volatile oil containing menthol 7-48\%, menthone 20-46\%, methyl acetate $3-10 \%$, menthofuran $1-17 \%$ and $1,8-$ cineol 3-6\%. Mentha oil also contains small amounts of many additional compounds including limonene, pulegone, caryophyllene and pinene (Leung, 1980).

Papaya, botanical name Carica papaya, is an lozenge tropical fruit, often seen in orange-red, yellow-green ad yellow-orange hues, with a rich orange pulp. Many benefits of papaya owed due to high of photolytic enzymes like papain and chymopapain which have antiviral, antifungal and antibacterial properties (Aravind, 2013). Papaya fruit is one of the best sources of vitamins and contain a lot of vitamins $\mathrm{A}$ and $\mathrm{C}$ and is considered to act as mild laxative. It has a neutral taste that can considerably improved by the addition of passion fruits to make soft drink, jam and various preserves. Papaya fruits are harvested during several months of the year. Papaya is one of the bland tropical fruits that may require acidification to ensure a safe product when processed by normal methods, (Rutledge, 1996).

Mango (Mangiferaindica L. Anacardiacea) is one of the most important tropical fruits in the world and 
currently ranked $5^{\text {th }}$ in total world production among the major fruit crops (FAO, 2004).

\section{Material and Methods}

\section{Raw Materials:}

1. Dark red Roselle calyces (Hibiscus sabdariffa) were purchased from local market in delta Egypt and origin were grown in Upper Egypt (Aswan).

2. Fresh green mint leaves (MenthaPiperita) were purchased from local market (Egypt).

3. Ripe papaya fruits (Carica papaya L.) were purchased from local market in delta area (Egypt) in its season 2014.

4. Ripe mango fruits (Mangiferaindica) were purchased from local market in delta area (Egypt).

5. Sugar (sucrose) was purchased from local market, Egypt.

6. Pectin was purchased from Danisco Co. (Czech).

7. Monohydrated citric acid was imported from Rzbc Co. (China).

\section{Methods:}

\section{Technological methods:}

\section{Preparation of Roselle (Hibiscus sabdariffa) jam: Preparation of Roselle extract:}

Dried hibiscus calyces were washed with cold water to remove dust and small impurities, Soaked in cold watr with ratio $1: 10$ (dried calyces : water) for 6 hours till the calyces swollen then boiled with its water till the extract's TSS reach $6.5 \%$ Brix.

\section{Jam Preparation:}

Filtered the previous extract from the calyces using a stainless mesh $1.5 \mathrm{~mm}$ and cheesecloth, preparing hibiscus jam $-62 \%$ concentration, $0.2 \%$ pectin usageas the following recipe:

(Hibiscus extract $6.5 \%=900 \mathrm{ml}$, Sugar $($ Sucrose) $=$ $1.5 \mathrm{~kg}$, Pectin=10 gm and Citric acid solution $42 \%=12 \mathrm{ml})$.

Sugar $(1.5 \mathrm{~g})$ was added to hibiscus extract $(900$ $\mathrm{ml})$ the solution was stirred till sugar totally soluble $(5 \mathrm{~min})$, the pectin was added as a pectin solution $5 \%$ Brix then the mixture was cooked at $80 \mathrm{C}^{\circ}$ for 10 min till concentration reach to $62 \%$, as measured by hand held refractometer ( Atago - 30:80 master hand held - Japan ). Finally Citric acid (12 $\mathrm{ml}$ ) was added as a solution $42 \%$ to form the jellification pectin net, after the mixture temperature reached to $90 \mathrm{C}^{\circ}$ and then settled for $3 \mathrm{~min}$

\section{Preparation of mint (MenthaPiperita) Jam Preparation of mint extract:}

Fresh green mint leaves were washed boiled with water b $1 \mathrm{wt}$ : 10volume for $30 \mathrm{~min}$ until the extract brix reach $4.5 \%$.

\section{Jam preparation:}

The leaves extract were filtered using a stainless mesh and cheesecloth, preparing mint jam 62\% concentration as the following recipe:

(Mint extract $4.5 \%=500 \mathrm{ml}$, Sugar=750 gm, Pectin=10 gm, Citric acid sol. $42 \%=6 \mathrm{ml}$ and Mint flavor $=0.25 \mathrm{ml})$

Sugar $(750 \mathrm{gm})$ was added to mint extract $(500$ $\mathrm{ml})$ the solution was stirred till sugar totally soluble (5min), the pectin was added ( $10 \mathrm{gm})$ as a pectin solution 5\% Brixthen the mixture was cooked at 80 $\mathrm{C}^{\circ}$ for $10 \mathrm{~min}$ till concentration reach to $62 \%$, as measured by hand held refractometer (Atago - 30:80 master hand held - Japan ). Finally Citric acid was added $(6 \mathrm{ml})$ as a solution $42 \%$, after the mixture temperature reached to $90 \mathrm{C}^{\circ}$ and settled for $3 \mathrm{~min}$ the mint flavor was added $(0.25 \mathrm{ml})$ to enhance the weakness of mint natural extract's flavor.

Preparation of papaya (Carica papaya $L$.) jam Preparation of papaya fruit pulp:

Ripe fruits were washed, peeled then the inner seeds were removed, juiced by electric blinder (Moulinex France) and stored in a freezer at $-4 \mathrm{C}^{\circ}$ until using.

\section{Jam preparation (original flavor)}

The following recipe was used for jam preparation: (Papaya pulp $6 \%=600 \mathrm{gm}$, Sugar=750 gm, Pectin=7 gm and Citric acid sol. $42 \%=7 \mathrm{ml}$ )

Sugar (750 gm) was added to papaya fruit pulp (600 gm) the mixture was stirred till sugar totally soluble $(5 \mathrm{~min})$, the pectin was added as a pectin solution 5\% Brix then the mixture was cooked at 80 $\mathrm{C}^{\circ}$ for $15 \mathrm{~min}$ till concentration reach to $62 \%$, as measured by hand held refractometer ( Atago - 30:80 master hand held - Japan ). Finally Citric acid was added $(7 \mathrm{ml})$ as a solution $42 \%$ to form the jellification pectin net, after the mixture temperature reached to $90 \mathrm{C}^{\circ}$ and settled for $3 \mathrm{~min}$.

\section{Preparation of Papaya and Mango jam mixture:}

Mango pulp (25\%) was mixed with papaya pulp $(75 \%)$ and processed as the recipe (Papaya pulp 6 $\%=450$ gm, Mango pulp $15 \%=60$ gm, Sugar $=750$ gm, Pectin=7 gm and Citric acid sol. $42 \%=5.5 \mathrm{ml}$ )

Sugar $(750 \mathrm{gm})$ was added to papaya fruit pulp (45m gm) the mango pulp was added (60 gm ) the mixture was stirred till sugar totally soluble ( $5 \mathrm{~min})$, the pectin was added as a pectin solution $5 \%$ Brix then the mixture was cooked at $80 \mathrm{C}^{\circ}$ for 15 min till concentration reach to $62 \%$, as measured by hand held refractometer ( Atago - 30:80 master hand held - Japan ). Finally Citric acid was added $(7 \mathrm{ml})$ as a solution $42 \%$ to form the jellification pectin net, after the mixture temperature reached to $90 \mathrm{C}^{\circ}$ and settled for $3 \mathrm{~min}$.

\section{Chemical and physicochemical analysis}

Moisture, Total soluble solids (T.S.S.) as Brix, $\mathrm{pH}$ value, ash, Crude fiber and protein contents as well as Total and reducing sugars were determined according to AOAC, 2012. 
Carbohydrates were determined by difference.T.S.S (total soluble solids): was determined by Hand held refractometer (Atago - 30:80 master hand held Japan) in cooking step.

Total pectic substances contents were determined by the method of Carre and Hayness, which was described by (Pearson, 1976).

Determination of minerals:

Minerals content were determined according to (AOAC ,2012)using Perkin-Elmer, 2380, Atomic Absorption Spectroscopy (AAS) apparatus in central laboratory of Faculty of Agric., Moshtohor. Benhauniversity .

\section{Preparation of samples for analysis:}

About $1 \mathrm{~g}$ of food product was placed in a previously ignited crucible and ashed for about 6-8 $\mathrm{hr}$ at 500-559 in a muffle furnace. After complete ignition, contents of crucible were transferred quantitatively to $100 \mathrm{ml}$ volumetric flask with a solution of $0.1 \% \mathrm{HCl}$ (A.R. grad) and volume was completed to the mark.

Determination of ascorbic acid:

Ascorbic acid determination using the 2,6dichorophenol indophenol dye titration method of (AOAC, 2012).

Rheological measurements:

Viscosity measurement was carried out by the Brookfield Digital Viscometer Model DV-II+ with 8 rotational speeds for comprehensive data gathering $(5,10,15,20,25,30,50$ and $100 \mathrm{rpm})$ according to El-Mansy et al., 2000 and Sharoba $\boldsymbol{e t}$ al., 2012.

Consistency (Spread ability): Was determined by consist meter (model no .0121 England).

Microbiological analysis :

Total viable bacterial count, yeast and mold were determined according to APHA (1992).

The microbiological media (total bacterial count (TBC) using nutrient agar medium and yeast $\&$ mold count using potato dextrose agar (PDA). Ten $\mathrm{ml}$ of each sample were suspended in sterilized bottle containing $90 \mathrm{ml}$ of sterilized water. The suspension was used for preparing serial dilution of 10-1, 102 and 10-3. One $\mathrm{ml}$ from each dilution was transferred to sterilized Petri dishes (three replicates). Suitable media was poured in plates before incubation. The plates of total bacterial count were incubated at $35^{\circ} \mathrm{C}$ for $48 \mathrm{hrs}$. While plates of yeasts and molds were incubated at $25^{\circ} \mathrm{C}$ for 3 days. The counts were calculated per one $\mathrm{ml}$ of sample as colonies formed unit (CFU).

Sensory evaluation:

Sensory properties (color, taste, aroma, etc...) of all jams were evaluated by the staff at Hero MEA Company, according to the method of (Lindly et al. 1993).

\section{Statistical analysis:}

Statistical analysis was carried out using Complete Randomized Design (CRD) giving analysis of variance (AVOVA) for significance at $5 \%$ of each treatment. Data of chemical composition of ingredients and formulas were expressed as mean of three replicates + standard error (SE). Data for the sensory evaluation of all formulas were subjected to the analysis of variance followed by multiple comparison using LSD $(\mathrm{P}<0.05)$ according to Snedecor and Cochran, 1989.

\section{Result and discussions}

Quality characteristics of raw fruits, vegetable and plant sources:

Fruits puree and juice were prepared and extracted in laboratory, and then analyzed for moisture, total solids, ash, fat, protein, total sugars, total pectic substances, fiber, and ascorbic acid (Table 1).

The results of chemical composition and physical properties for ingredients used for the preparation of jam formulas were in agreement with those obtained by MaCance and Widdowson's (1992); Matuk, et al. (1996); EL-SayedSahar, (2000); Abd-Elaziz, et al. (2000); Tsen and King (2002); Alline, et al. (2003); El-Mansy, et al. (2003); Nourian, et al. (2003); Ramulu and Rao (2003); Wall, (2006); Bahlol, et al., (2007) and Mehder, (2009).

proximate composition of jam blends :

Data in Table (2) indicated that moisture and total solids content in jam formulas nearly varied. This is due to the adding different kinds of fruits and vegetables. Also all formulas had the highest level of ash content for the same reason.

pH and titritible acidity of jam recipes :

Titratable acidity and $\mathrm{pH}$ values are important as it affected on the taste and flavor. The $\mathrm{pH}$ values indicated that all formulas were bit little acid food Table (3). (complet the data).

\section{Minerals mineral in jam blends}

The mineral composition of fruits and vegetables can reflect the trace mineral of soil in a geographic region (Forster et al., 2002 and Wall, 2006) and varies with climate, maturity, cultivars, and agricultural practices. Some minerals content of the jam formulas are shown in Table (4). Calcium is particularly essential for young children (Whitney, et al., 1990). The calcium content of all formulas ranged between 13.86 to $10.63 \mathrm{mg} / 100 \mathrm{~g}$. For, sodium, it is clear that mint jam had the highest value while hibiscus jam had the lowest value. The trace elements (magnesium and zinc), contents were ranged from 18.86 to 8.86 and 1.89 to $1.58 \mathrm{mg} / 100 \mathrm{~g}$, respectively. The variation of the minerals content in all formulas may be due to the different content of these elements in raw ingredients. The phosphor content ranged between 7.55 to $6.27 \mathrm{mg} / 100 \mathrm{~g}$. 
$\mathrm{Ca} / \mathrm{P}$ ratio in experimental jam blends were had the best $\mathrm{Ca} / \mathrm{P}$ ratio according to The FAO/WHO (1985), that recommended the ratio of calcium to phosphorus must not exceed the ratio $2: 1$ and not less than $(1 / 2-1)$.

From the results of minerals it could be concluded that the blends are considered as a source for some minerals. The results of minerals contentfor the prepared jam formulas were in agreement with those obtained by Riaz et al.(1999), Ehsan, et al.( 2002), Bahlol, et al.(2007), Hewedy, (2007), Mehder, (2009), Singh et al. (2009) and Souad et al.(2012).

\section{Sensory evaluation of jam blends:}

The three jams were evaluated for color, taste, odor, consistency (texture), mouth feel and over all acceptability by 20 adults from the staff member of Hero MEA Company. The scores were tabulated in the Table (5). The data indicated that all of the jam had high score in all characters which used in the sensory evaluation. From the data in the Tables as we shown for color, taste, texture and mouth feel, first group had scores more than $90 \%$ in all previous characters. Papaya + mango Jam blend had higher scores among other blends in all sensory food characters. compare these jam with control sample.

\section{Microbilogical aspects of jam blends:}

The overall bacteriological status of the blinds was observed to be satisfactory. The obtained results revealed that the total viable bacterial count was 45 and $59 \mathrm{CFU} / \mathrm{g}$ for ( mint jam\&hibiscus jam), respectively, as indicated in Table (6).

The low counts of the examined blends indicated adequate thermal process, good quality of raw materials and as a result of the good different processing conditions under which the production of blends was carried out.

Mesophilic spore formers bacterial count was 19 and $21 \mathrm{CFU} / \mathrm{g}$ for blends (mint jam \&papaya + mango jam), respectively. However, yeasts and moulds, coliform group, Salmonella and Staphylococcus aureus were found to be absent in all the blends. The microbiological results were in agreement with many authors such as Wadud, et al. (2004); Soliman (2001); Bahlol, et al. (2007); Hewedy, (2007); and Mehder, (2009).

The microbiological results suggested that the blends are suitable to be submitted for sensory evaluation by adult panelists, and it was safe for infant and adults eating.

\section{Rehligocal proparties of jam blends:}

In the food industry, rheological characteristics of concentrated fruit juices and jams are a significant important property in addition to chemical and physical properties. Moreover, rheological characteristics depend on both the chemical composition of fruits and processing conditions. However, knowledge of the flow behavior of vegetable and fruit juices will be useful in quality control, calculating energy usage, process control and equipment selection (Kaya and Belibagli, 2002, Bahlol, et al.(2007) and Sharoba and Ramadan (2010). Viscosity; a rheological property, is also considered as an important physical characteristic related to the quality of liquid food products. Rheological behavior of food depends on various factors like temperature, composition and total solids content.

The shear stress - shear rate data obtained during experimentation were applied to some rheological models (Bingham, power law, IPC Paste, Herschel \& Buckley and Casson's models). The power law and Herschel \& Buckley (Eq., 1 and 2) models were the best models described the flow behavior of the analysed jam formulas. The power law model was applied to determine the consistency coefficient $(\mathrm{k})$ and flow behavior index (n),

Jam formulas exhibited yield stress, which decreased exponentially with temperature. At higher temperatures, due to rupture, the food structure becomes weak resulting in the lowering of yield stress (Sharoba and Ramadan, 2010). The same trend was found in all jam blends. The flow behavior index (n) was less than unity and increased with temperature for the 3 jam blends. This indicated that the jam blends behaved as a shear-thinning (pseudoplastic) fluid. The numerical values of the rheological parameters of the all 3 jam blends showed that there was little difference in their flow behavior index. Because pseudo plasticity is related to the average site of the particle of the disperse phase, it can be assumed that all samples had particles of similar size, due to a similar finishing operation. The plastic viscosity $(\eta)$ was found to decrease with increased shear rate, which also proves its pseudoplastic or shear thinning nature. The coefficients for Power law model are given in Table (7). 
Table 1. Proximate composition of raw materials

\begin{tabular}{lccc}
\hline Components & Hibiscus puree & Mint puree & Papaya puree \\
\hline Moisture \% & 86.26 & 86.01 & 87.02 \\
\hline Total solids \% & 13.74 & 13.62 & 12.98 \\
\hline Ash \% & 1.03 & 3.48 & 0.67 \\
\hline Fat \% & 1.17 & 2.2 & 0.47 \\
\hline Protein \% & 2.45 & 1.75 & 0.73 \\
\hline Fiber \% & 2.76 & 6.28 & 1.3 \\
\hline Total sugars \% & 2.31 & 3.39 & 7.12 \\
\hline Reducing sugars \% & 1.40 & 2.32 & 2.98 \\
\hline Non reducing sugars \% & 0.91 & 1.07 & 4.13 \\
\hline $\begin{array}{l}\text { Total pectic substances } \\
\%\end{array}$ & 1.08 & 0.72 & 1.88 \\
\hline
\end{tabular}

Table 2. Proximate composition of prepared jam blends

\begin{tabular}{|c|c|c|c|c|c|c|c|c|}
\hline Flavor & $\begin{array}{c}\text { Moisture } \\
\%\end{array}$ & $\begin{array}{c}\text { Crude } \\
\text { protein }\end{array}$ & Fat & Ash & Vit. C & $\begin{array}{l}\text { Crude } \\
\text { fibers }\end{array}$ & TSS & $\begin{array}{c}\text { Energy } \\
\text { values } \\
\text { Kcal./100 g }\end{array}$ \\
\hline $\begin{array}{l}\text { Hibiscus } \\
\text { jam }\end{array}$ & 32.1 & 1.893 & 0.564 & 1.307 & 12.24 & 2.147 & 62.3 & 91.293 \\
\hline Mint jam & 32.2 & 1.839 & 0.423 & 1.027 & 11.14 & 1.921 & 62.1 & 86.763 \\
\hline $\begin{array}{l}\text { Papaya + } \\
\text { Mango 25 } \\
\% \text { jam }\end{array}$ & 32.3 & 1.808 & 0.416 & 1.042 & 41.01 & 2.281 & 61.9 & 83.868 \\
\hline
\end{tabular}

Table 3. $\mathrm{pH}$ and titritible acidity of jam blends (on wet basis*).

\section{Blends No.}

Hibiscus jam (B1)

Mint jam (B5)

(Papaya75\%+Mango $25 \%$ ) jam (B6)

$*$ Value represents average of three determinations
pH values

$\begin{array}{ll}3.0 & 1.4 \\ 3.2 & 1.2 \\ 3.1 & 1.3\end{array}$

Table 4. Minerals content of jam blends (mg/100g on wet weight basis)

\begin{tabular}{cccccccccc}
\hline & \multicolumn{1}{c}{ Minerals (mg/100g.) } \\
\cline { 2 - 11 } Blends No. & \multicolumn{1}{c}{ Macro elements } & \multicolumn{3}{c}{ Micro elements } \\
\cline { 2 - 11 }$y$ & $\mathrm{Ca}$ & $\mathrm{Kg}$ & $\mathrm{Na}$ & $\mathrm{P}$ & $\mathrm{Cu}$ & $\mathrm{Fe}$ & $\mathrm{Mn}$ & $\mathrm{Zn}$ \\
\hline Hibiscus jam & 12.86 & 124.29 & 18.86 & 47.99 & 6.55 & 0.163 & 4.63 & 0.145 & 1.58 \\
\hline Mint jam & 10.63 & 140.57 & 9.08 & 60.31 & 6.27 & 0.380 & 1.69 & 0.097 & 1.89 \\
\hline $\begin{array}{c}\text { Papaya + } \\
\begin{array}{c}\text { Mango 25 \% } \\
\text { jam }\end{array}\end{array}$ & 13.86 & 122.29 & 8.86 & 51.38 & 7.55 & 0.173 & 2.03 & 0.103 & 1.68 \\
\hline
\end{tabular}

Table 5. Sensory evaluation of the prepared jam blends.

\begin{tabular}{lccccccc}
\hline & \multicolumn{7}{c}{ Sensory attributes } \\
\cline { 2 - 8 } Blends & Color & Taste & Odor & Consistenc & Mouth feel \\
& $(20)$ & $(20)$ & $(20)$ & $\begin{array}{c}\text { Texture) } \\
(20)\end{array}$ & $\begin{array}{c}\text { Fruit } \\
(10)\end{array}$ & $\begin{array}{c}\text { Overall } \\
(10)\end{array}$ & $\begin{array}{c}\text { Occeptability } \\
(100)\end{array}$ \\
\hline \multirow{2}{*}{ Hibiscus jam } & $18.80 \mathrm{a}$ & $20.00 \mathrm{a}$ & $20.00 \mathrm{a}$ & $15.40 \mathrm{c}$ & $10.00 \mathrm{a}$ & $10.00 \mathrm{a}$ & $92.80 \mathrm{a}$ \\
& \pm 0.38 & \pm 0.72 & \pm 0.80 & \pm 0.39 & \pm 0.32 & \pm 0.21 & \pm 1.82 \\
\hline \multirow{2}{*}{ Mint jam } & $17.00 \mathrm{~b}$ & $20.00 \mathrm{a}$ & $17.65 \mathrm{~b}$ & $16.10 \mathrm{c}$ & $10.00 \mathrm{a}$ & $8.71 \mathrm{~b}$ & $93.20 \mathrm{a}$ \\
& \pm 0.39 & \pm 0.87 & \pm 0.54 & \pm 0.41 & \pm 0.47 & \pm 0.83 & \pm 1.98 \\
\hline Papaya + Mango & $18.55 \mathrm{a}$ & $19.20 \mathrm{a}$ & $20.00 \mathrm{a}$ & $19.70 \mathrm{a}$ & $9.25 \mathrm{a}$ & $10.00 \mathrm{a}$ & $95.40 \mathrm{a}$ \\
$25 \%$ jam & \pm 0.77 & \pm 0.55 & \pm 0.21 & \pm 0.26 & \pm 0.87 & \pm 0.62 & \pm 1.73 \\
\hline L.S.D at $\mathrm{p} \leq 0.05$ & 1.75 & 1.84 & 1.46 & 1.59 & 1.15 & 1.22 & 5.22 \\
\hline *Values represent of 20 panelists (Mean \pm S.E.) \\
* a, b, ... There is no significant difference (p $\geq 0.05)$ between any two means have the same superscripts, within the same \\
acceptability attribute.
\end{tabular}


Table 6. Microbilogical aspects of jam blends (CFU/g).

\begin{tabular}{lcccc}
\hline Blends No. & TVBC $^{*}$ & MSB $^{*}$ & Y\&M** & Coliform \\
\hline Hibiscus jam (B1) & 59 & 19.5 & ND & ND \\
\hline Mint jam (B5) & 45 & 19 & ND & ND \\
\hline (Papaya75\% + Mango 25\%) jam (B6) & 50 & 21 & ND & ND \\
\hline
\end{tabular}

* (TVBC) Total viable bacterial count

(MSB) Mesophilic Spore formers bacteria

*** Yeasts and Moulds

Table 7. Rheological parameters of jam blends

\begin{tabular}{|c|c|c|c|c|c|c|c|}
\hline \multirow{2}{*}{ Jam Blends } & \multirow{2}{*}{$\begin{array}{c}\text { Temp. } \\
\left({ }^{\circ} \mathrm{C}\right)\end{array}$} & \multicolumn{3}{|c|}{ Power law } & \multicolumn{3}{|c|}{ Bingham } \\
\hline & & $\mathbf{K}$ & n & $\mathbf{r}^{2}$ & $\eta_{\mathbf{B}}$ & $\tau_{0 \mathrm{~B}}$ & $\mathbf{r}^{2}$ \\
\hline \multirow[t]{2}{*}{ Hibiscus jam } & 5 & 22.63 & 0.287 & 0.999 & 36.16 & 5.65 & 0.999 \\
\hline & 100 & 18.67 & 0.274 & 0.984 & 27.61 & 4.11 & 0.999 \\
\hline \multirow{2}{*}{ Mint jam } & 5 & 20.04 & 0.298 & 0.999 & 38.11 & 5.71 & 0.999 \\
\hline & 100 & 14.08 & 0.285 & 0.991 & 28.49 & 4.18 & 0.989 \\
\hline \multirow{2}{*}{ Papaya + mango $25 \%$ jam } & 5 & 29.03 & 0.342 & 0.999 & 44.06 & 7.41 & 0.999 \\
\hline & 100 & 23.12 & 0.342 & 0.984 & 34.43 & 5.76 & 0.999 \\
\hline
\end{tabular}

\section{Where:}

$(\mathrm{k})$ : Consistency index $\left(\mathrm{mPa} . \mathrm{s}^{\mathrm{n}}\right) \quad$ (n): Flow index (dimensionless).

$\tau_{\mathrm{OB}}=$ Yield stress, shear stress at zero shear rate, $(\mathrm{Pa}) \eta_{\mathrm{B}}=$ Plastic viscosity $(\mathrm{Pas})$

$\mathrm{r}^{2}=$ Correlation coefficients

\section{Refrences}

A.O.A.C. (2012): Official Methods of Analysis. Association of Official Analytical Chemists. Published by the AOAC. International 19the ed., MARYLAND, USA.

Abd-Elaziz, S. N.; Helmy, I. M. F. and AbdelHamied, A.A. (2000) Efficiency of some drying methods on quality of papaya fruits. Egyptian J. of Nutr., (xv) 2: 145-119.

Alline, C.C.R.; Rosiance, L.C. and Miriam D.H. (2003) Rheological properties and colour evaluation of papaya during osmotic dehydration processing. J. of Food Eng., 59: 129-153.

APHA (1992) Compendium of methods for the microbiological examination of foods. Inc. American Public Health Association Washington DC.

Aravind, G ; Debjit Bhowmik; Duraivel .S and Harish . G (2013) Traditional and medicinal uses of Carica Papaya.Journal of medicinal plants studies, issue 1 page 7 - 15 .

Bahlol, H.E.M.; Sharoba, A.M. and El-Desouky, A.I. (2007). Production and evaluation of some food formulas as complementary food for babies using some fruits and vegetables. Ann. of Agric. Sc., Moshtohor, 45(1): 147-168.

Ehsan, E.B., Naeem, Z.P. Ghafoor, A. and Bahtti, M.S. (2002). Development, standardization and storage studies on watermelon lemon jam. Pakistan Journal of Food Science 12 (3-4): 21-24.

El-Mansy, H. A.; El-Desouky, A. I.; Nezam ElDin, A. M. and Hasnaa, M. A. (2003) Production of some formulated food mixtures for use as food source for some minerals and vitamins deficiency. Annals of Agric. Sc. Moshtohor: 41: (2) 751-765.

El-Mansy, H.A.; Sharoba, A.M.; Bahlol, H.El.M. and El-Desouky, A.I. (2005). Rheological properties of mango and papaya nectar blends. Ann. Of Agric. Sc., Moshtohor, 43(2): 665-686.

El-Mansy, H.A.; Bahlol, H.E.; Mohamed, M.H. and Sharoba, A.M. (2000) Comparative studies of chemical and rheological properties for orange juice and its concentrates. Ann. of Agric. Sc. Moshtohor, 38(3): 1557-1574.

El-Sayed, M.Z. Sahar (2000) Technological and biological studies on carrot and sweet potato. Ph.D. Thesis, Food Sci. and Tec. Dep., Fac. of Agric., Cairo Univ., Egypt.

EOS (2013) Egyptien stanaderd orgnazition. Prserved fruit products 129-2/2013

FAO/WHO, (1985) Energy and protein requirements, Report of a joint, FAO/WHO/UNU Expert consultation technical report, series No. 724, WHO, Geneva.

FAO Products Year Report (2004). Food and Agriculture Organization ISBN 92-5-105178. Rome, Italy.

Forster, M.P.; Rodriguez, E.; Martin, J.D.; Romero, C.D. (2002): Statistical differentiation of bananas according to their mineral composition. J. Agric. And Food Chem., 50: 6130-6135.

Hewedy, A.A. Dina (2007) Canned Baby Foods. M.Sc. Fac. of Agric., Mansoura Univ., Egypt.

Kaya, A., and Belibagli, K.B. (2002): Rheological of solid Gaziantep pekmez. J. of Food Eng., 54, 221-226.

Leung A, Foster S (1996). encyclopedia of common natural ingredients used in food, drugs 
and cosmetics secons edition. New York: John Wiley \& Sons. p 130-145 .

Leung, A. Y. (1980). Encyclopedia of Common Natural Ingredients used in food, drugs and cosmetics. New York: John Wiley \& Sons. p. 231.

Lindley, MG, Beyts, PK, Canales, I, Borrego, F.(1993)Flavor modifying characteristics of the intense sweetener neohespiridin dihydro chalcone. Journal of Food Science. 58: p592-594.

MaCance and Widdowson's (1992) The composition of food. Fifth revised and extended edition. The Royal Society of Chemistry and Ministry of Agric., Fisheries and Food.

Magya Kilima B. , Remberg SF (2014) Physiochemical ,minerals composition and antioxidant properties of Roselle ( Hibiscus sabdariffa L . extract, African journal of food V.14 No .3 pp 11-15.

Matuk, H.I.; Ali, A.M. and Ibrahim, K.Sh. (1996) Chemical and technological studies on production of carrot nectar. Egypt J. Appl. Sci., 11 (9) 74-88.

Mehder, A.U.A. (2009) Processing and Preservation of Some Baby's Food and Detection it's Contamination. Ph.D. Thesis, Nutrition and Food Science- Food technology, College of Education for Home Economics, Umm Al-Qura University, Makkah Almokarama, Kingdom of Saudi Arabia.

Nourian, F.; Ramaswamy, H. S. and Kushalappa, A. C. (2003) Kinetic change in cooking quality of potatoes stored at different temperatures. J. Food Eng., 60: 257-266.

Pearson D. (1976) The chemical analysis of food, 7th edn. Churchill, London.

Ramulu, P. and Rao, P. U. (2003) Total, insoluble and soluble dietary fiber contents of Indian fruits. J. of Food Composition and Analysis 16: 677685.

Riaz, M. N., Mohyuddin, G. and Al Haq, M.I. (1999). Physical, chemical and sensory characteristics of jams made from fresh and frozen strawberries. Pakistan Journal Arid Agriculture 2 (1): 51-60.

Rutledge, P. (1996)Production of non fermented fruit products. In Fruit Processing (ed. Arthey, D. and Ashurst, P.R. Blackie Academic \& Professional, an imprint of Chapman \& Hall.

Santanu B, Shinhare US (2010): Rheological, textural, micro-structural and sensory properties of mango jam. J. Food Eng., 100: 357-365.
Sharoba, A.M.; El-Desouky, A.I. and Mohamed, M.H. (2012): Effect of addition some hydrocolloids and sweeteners on flow behavior and sensory properties of papaya-apricot nectar blends. Journal of Food Processing \& Technology, 3(8) 170. http://dx.doi.org/10.4172/2157-7110.1000170.

Sharoba, A.M. and Ramadan, M.F. (2010). Rheological behavior and physicochemical characteristics of goldenberry (physalis peruviana) juice as affected by enzymatic treatment. Journal of Food Processing and Preservation 35, 201-219.

Singh, S.S, Singh, S.P.J and Singh, D. (2009). Quality changes in fruit jams combinations of different fruits pulps. Journal of Food Processing and Preservation (33):41-57.

Snedecor G.W. and Cochran W.G. (1989) Statitical methods. 8th ed. Iowa State Univ. Press, Ames, Iowa.

Soliman, A.S. (2001) studies on some physical and thermal properties of Anna apple cultivar. Ph.D. Thesis, Fac. Agric., Moshtohor, Zagazig Univ., Egypt.

Souad, A.M., Jamal, P. and Olorunnisola, K. S. (2012) Effective jam preparations from watermelon waste. International Food Research Journal 19(4): 1545-1549.

The Prevention of Food Adulteration Rules (1955). A.16.07.287.

Tsen, J. H. and King, V. A. E. (2002) Density of banana puree as a function of soluble solids concentration and temperature. J. of Food Eng., 55: 305-308.

Wadud, S; Abid, H.; Ara, H.; Kosar, S. and Shah, W. H. (2004) Production, quality evaluation and storage stability of vegetable protein-based baby foods. Food chem., 85:175-179.

Wall, M. M. (2006) Ascorbic acid, vitamin A and mineral composition of banana (Musa sp) and papaya (Carica papaya) cultivars grown in Hawaii. J. of Food Composition and Analysis, 19: 434-445.

Whitney, N.E. and Rolfes S.R. (1993). Thetrace minerals. In Understanding Natrition PP. 442. St Plan: West Publishing CO.

WHO (1985) Human food requirements. Hand Book. From the regional office of the world Health organization of East of Mideteranean, Alexs. Egypt. 


\section{إعداد خلطات مربي جديدة باستخدام مصادر نباتية غير تقليدية \\ عبدالله سلام شافعى سلام ، علاء البلتاجى ، أبوالفتح البديوى

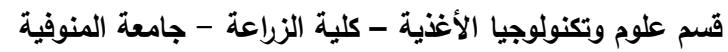 \\ شركة هيرو مصر والثرق الأوسط للصناعات الغذائية - قليوبية - مصر ولئه}

فى هذه الدراسة نم تصنيع نوعيات جديدة من المربات الغير تقليدية فى السوق المصرى أو السوق العالمى من فاكهة وخضروات ومواد

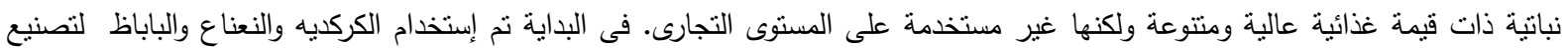
نوعيات جديدة من المربات وبعد إجراء التقييم الحسى لها حصلت عينات مربى الباباظ على قبول متوسط بينما حصلت مربى كل من الكركديه والنعناع على قبول حسى عالى. ولهذا أتجهت الدراسة الى إضافة لب المانجو الي مربي الباباظ بنسبة 25\% ، وذللك لعمل التوليفات المختلفة وبعد العديد من التجارب الحسية بواسطة المحكميين الحسيين حصلت الثنلاث توليفات عالى نتائج تقيبيم حسى عالى وهى (مربى الكركديه، مربى النعناع، مربى الباباظ مع نسبة لب مانجو 25\%). تم تحليل المواد الخام المستخدمة فى الدراسة كيميائيا وتغذويا وأوضحت النتائج أرتفاع هذه المواد الخام فى الفيتامينات والأملاح المعدنية وأحتوائها على نسبة من البروتين وإرتفاع محتوياتها من الكربوهيدرات. وتم تحليل الثناث عينات المحضرة من المربى الغير تقليدية تغذويا و بعد ذلك قيمت هذه الخلطات ميكروبيولوجيا لدراسة أمانها قبل تقييمها حسيا ووجد أنها أمنة من الناحية الميكروبيولوجية. وتم قياس الخواص الريولوجية وأوضحت نتائج التحليل الريولوجى أن جميع الخلطات المختارة تسلك السلوك الغير نيوتينى، ولذا فئلئ

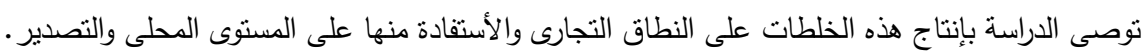
الكلمات المساعدة: مريى - خلطات غير تقليدية - التركيب الكيماوى والتظذوى - الخصائص الحسية - الخواص الريولوجية . 